\title{
Drivers of invasive tree and shrub natural regeneration in temperate forests
}

\author{
Marcin K. Dyderski • Andrzej M. Jagodziński
}

Received: 15 November 2017/ Accepted: 13 March 2018/Published online: 19 March 2018

(C) The Author(s) 2018

\begin{abstract}
We assessed drivers of ecological success along resource availability gradients for three invasive woody species: Prunus serotina Ehrh., Quercus rubra L. and Robinia pseudoacacia $\mathrm{L}$. We aimed to check how much of invasion success, measured by invader biomass, is explained by propagule pressure and plant community invasibility. Using 3 years of observations from 372 study plots $\left(100 \mathrm{~m}^{2}\right.$ each $)$ in temperate forests of Wielkopolski National Park (Poland) we investigated the hierarchy of predictors and partial dependencies using the random forest method. Our study indicated that propagule pressure explained more variance in success of invaders than invasibility-describing availability of resources and competitors in understory vegetation. We also found different responses of seedlings and saplings, connected with dependence on stored carbohydrates, which decreased seedling responses to resource availability gradients.
\end{abstract}

Electronic supplementary material The online version of this article (https://doi.org/10.1007/s10530-018-1706-3) contains supplementary material, which is available to authorized users.

M. K. Dyderski $(\bowtie)$ · A. M. Jagodziński

Institute of Dendrology, Polish Academy of Sciences,

Parkowa 5, 62-035 Kórnik, Poland

e-mail: Marcin.Dyderski@gmail.com

M. K. Dyderski · A. M. Jagodziński

Department of Forest Protection, Faculty of Forestry, Poznań University of Life Sciences, Wojska Polskiego

71c, 60-625 Poznań, Poland
However, resource availability (light and leaf litter predictors) had greater influence than predictors describing understory vegetation. Based on importance and response strength the species studied may be arranged by decreasing requirements for soil fertility and acidity: $P$. serotina $<Q$. rubra $<R$. pseudoacacia, whereas for light requirements and competition vulnerability the order is: $P$. serotina $>Q$. rubra $>R$. pseudoacacia. However, low light requirements of $R$. pseudoacacia may be biased by high proportion of sprouts supplied by parental trees. Results provide guidelines for effective management of invasive woody species in forest ecosystems and describe complex interactions between factors studied on ecological success of invaders.

Keywords Propagule pressure - Invasibility · Prunus serotina $\cdot$ Quercus rubra $\cdot$ Robinia pseudoacacia $\cdot$ Seedlings and saplings biomass

\section{Introduction}

Among functional groups of invasive plant species, woody plants are distinguished by their long lifespan (Richardson 1998; Richardson et al. 2000; Richardson and Rejmánek 2011). For that reason their establishment and first year of life is crucial for further development and dispersal (Baraloto et al. 2005). Thus, as dispersal is the key factor that allows 
naturalized species to become invasive (Richardson et al. 2000; Chytrý et al. 2008; Dyderski and Jagodziński 2016), ecological success of young regeneration determines the ultimate success of woody invaders. In comparison with short-lived (herbaceous) taxa, assessment of woody species requires more complex studies, also accounting for more predictors and potential interactions (e.g. Richardson 1998; Pyšek et al. 2014; Brundu and Richardson 2016).

Natural regeneration of both native and invasive species faces numerous limiting factors. The abiotic conditions most limiting to growth of young trees are usually water, light and nutrient availability (Niinemets and Valladares 2006; Ellenberg and Leuschner 2010). However, levels of these factors are also influenced by other species co-occurring within the plant community (Tilman 1986). Competitive potential of a plant species is a derivate of its life strategy (Westoby 1998; Grime 2006), which results from its functional traits and their level of fitness to environmental conditions, particularly expression of resource acquisition strategies, e.g. specific leaf area, leaf photosynthetic capacity or specific root length (Cornelissen et al. 2003; Pierce et al. 2013; Díaz et al. 2016; Kunstler et al. 2016). Natural regeneration of woody species competes with different species and may "win" and reach the next level of development only in particular conditions. Thus, ecological success of invasive species depends on characteristics of the recipient plant community-habitat invasibility, which is determined by level of resources (Davis et al. 2000; Godefroid et al. 2005; Funk 2008; Paquette et al. 2012; González-Muñoz et al. 2014), and potential competitors (Chmura 2004; Chmura and Sierka 2005, 2007; Godefroid et al. 2005; Knight et al. 2008).

Biological invasions are driven by three connected factors: habitat invasibility, alien species invasiveness and propagule pressure-quantity and quality of propagules able to establish in new sites (Richardson et al. 2000; Davis et al. 2005; Jeschke 2014). Among them, propagule pressure is the obligatory factor determining invasion success (Lonsdale 1999; Lockwood et al. 2005; Vanhellemont et al. 2009). Numerous studies have confirmed its importance at both large (Křivánek et al. 2006; Pyšek et al. 2009, 2015; Woziwoda et al. 2014) and small spatial scales (Pairon et al. 2006; Deckers et al. 2008; Vanhellemont et al.
2009; Jagodziński et al. 2015; Bonilla and Pringle 2015). Propagule pressure seems to be a crucial driver of relationships between habitat invasibility and ecological success of invasive species. Although most of these interactions were studied within relatively short resource gradients, covering few habitat types (Vanhellemont et al. 2009; Aslan et al. 2012; Terwei et al. 2013; Jagodziński et al. 2015), Davis et al. (2005) conceptualized the relationship between invasibility and propagule pressure as the concept of invasion pressure, which provided a framework to merge both groups of factors. Our previous study (Jagodziński et al. 2018a) also revealed the interactions between propagule pressure and invasibility, but only for one species and in an experimental system.

Despite existing knowledge of factors determining success of biological invasions, it remains unknown whether interactions between, and relative importance of, propagule pressure and invasibility across a wide range of forest types are similar to the limited types reported on by previous studies. Comprehensive review of the community ecology of invasive species (Gallien and Carboni 2017) indicated a lack of clarity on whether processes filtering species colonizing new communities vary along environmental gradients. Moreover, there is an insufficient number of studies on invasive species spread conducted in protected areas, which are especially threatened by biological invasions (Hulme et al. 2014).

We aimed to assess drivers of biomass along resource availability gradients for the three most frequent invasive woody species in temperate Europe (Wagner et al. 2017)_Prunus serotina Ehrh., Quercus rubra L. and Robinia pseudoacacia L.- to assess how much of invasion success (moving along an introduction-naturalization-invasion continuum), measured by invader biomass, is explained by propagule pressure and plant community invasibility. We hypothesized that: (1) propagule pressure explains more variance in ecological success of invaders than invasibility, according to previous studies (e.g. Lonsdale 1999; Jagodziński et al. 2015, 2018a), (2) total biomass of seedlings depends more on propagule pressure than for saplings, as seedlings are more dependent on dispersal than older plants, which require suitable conditions for survival (e.g. Beckage et al. 2005; Knight et al. 2008; Rodríguez et al. 2017), and (3) understory competition, expressed by functional diversity components, have larger effects on ecological success of the 
invasive species studied than surrogates of resource availability, as light competition limits occurrence of the species studied (Cierjacks et al. 2013; Jagodziński et al. 2015, 2018a). Because the three species studied differ in biology and ecology, we decided to characterize their invasiveness by comparing their responses to propagule pressure and habitat predictors on the background of their life history traits.

\section{Materials and methods}

Studied species

In European woodlands three alien woody species are most frequent: Prunus serotina Ehrh., Quercus rubra L. and Robinia pseudoacacia L. (Wagner et al. 2017). These species have been broadly recorded as invasive in Europe and all of them were widely introduced via forestry, in the eighteenth, nineteenth and seventeenth century, respectively (Muys et al. 1992; Woziwoda et al. 2014; Vítková et al. 2017). These species came from eastern North America and are widely distributed in Western and Central Europe, but their frequency decreases eastwards. $P$. serotina in its native range is a tree with valuable timber, but in Europe its introduction was not successful either in terms of timber production or soil improvement (Muys et al. 1992; Starfinger et al. 2003; Aerts et al. 2017). Its presence strongly influences nutrient cycling (Aerts et al. 2017; Horodecki and Jagodziński 2017). P. serotina is dispersed mainly by birds, up to $600 \mathrm{~m}$ from the seed source (Pairon et al. 2006; Jagodziński et al. 2015), however ca. $80 \%$ of fruits fall beneath the crown of the mother tree (Pairon et al. 2006). $Q$. rubra produces medium-value timber in Europe and due to its long lag-time is considered a weakly invasive species. Its dispersal is limited, as acorns mainly fall close to the parents and are not preferred by birds (Myczko et al. 2014; Bieberich et al. 2016), which are the main long-distance vectors of this species. $R$. pseudoacacia is a wind-dispersed pioneer tree species, important for wood production and providing nectar sources for pollinators, and is also widely used as an ornamental tree (Cierjacks et al. 2013; Vítková et al. 2017). This species transforms soils, due to symbiosis with nitrogen-fixing organisms (Rice et al. 2004). All these species invade forest ecosystems of temperate Europe, ranging from less fertile coniferous sites to the most fertile riparian sites.

Study area

We conducted our study in Wielkopolski National Park (WNP; W Poland; 52 $16^{\prime} \mathrm{N}, 16^{\circ} 48^{\prime} \mathrm{E}$ ). WNP covers 7584 ha and conserves mostly forest ecosystems and very diverse geomorphology connected with the last glaciation. According to the nearest meteorological station in Poznań (c.a. $15 \mathrm{~km}$ from WNP) mean annual temperature in $1951-2010$ was $8.4^{\circ} \mathrm{C}$ and annual precipitation was $521 \mathrm{~mm}$. Forests of WNP were heavily transformed by human activity, especially by former forest management, replacing mixed and broadleaved forests with monocultures of Scots pine. Moreover, before WNP establishment in 1957, the area was a place of numerous introductions of alien trees and shrubs, thus WNP is the national park in Poland with the highest number of alien woody species (Purcel 2009; Gazda and Szwagrzyk 2016). For that reason WNP provides a wide range of soil fertility and tree species composition, as well as variable propagule pressure of alien tree species, which makes WNP a good area for invasion ecology studies. All three species studied are abundant and are present both as an admixture in the tree stands and as monoculture tree stands (Purcel 2009). These advantages, together with known history of forest management and alien species introductions, make WNP a valuable area, especially for studies on biological invasions in forest ecosystems.

\section{Study design}

We used a set of 378 plots (squares $100 \mathrm{~m}^{2}$ in area) arranged in 21 blocks: nine for $Q$. rubra and six for $P$. serotina and $R$. pseudoacacia. We established more blocks for $Q$. rubra due to lower densities of this species, resulting in lower detection rates. Moreover, within blocks only the central part of each block is located in a parental (monoculture) stand of invasive species (for $P$. serotina, which occurs only as an admixture in tree stands, these are tree stands with high density of fruiting trees), and the remaining plots are also invaded by the other two species. One pair of plots was located within the invasive species monoculture (maternal stand). A second pair of experimental plots was located along each of four sides of the 
maternal stand (N, S, E, and $\mathrm{W})$, nearly outside the stand, at the invasion edge (Rodríguez et al. 2017), and a third pair of experimental plots was located $30 \mathrm{~m}$ further out from the second set of plot pairs (Fig. 1). This design produced 18 experimental plots with different distances from propagule sources-within the maternal stands, outside maternal stand borders and at a distance of $30 \mathrm{~m}$ from maternal stands. Due to the high level of spatial heterogeneity in tree stands, longer distances may result in biases in estimation of the distance effects. Therefore, four classes of distance from propagule source were distinguished: in the propagule source, near the propagule source, $30 \mathrm{~m}$ from the propagule source and further than $30 \mathrm{~m}$ (plots without a propagule source of the considered species in the nearest neighborhood). Despite concerns, this did not generate pseudoreplications, due to high spatial heterogeneity manifested in high variability of natural regeneration within plots. Due to systematic distribution of the plots, six of them were located in non-forested vegetation paths and these plots were excluded from analyses, thus the final number of plots was $n=372$. This number of plots covered almost whole scale of plant communities typical to Central European forest types-from coniferous forests with Pinus sylvestris on podzols and acidophilous Quercus petraea forests on brunic soil to Quercus roburCarpinus betulus-Acer pseudoplatanus-Tilia cordata, Fagus sylvatica and Quercus robur-Ulmus minorFraxinus excelsior forests on fertile haplic soils. Study plots covered ten forest types: Acer platanoides-Tilia cordata-Carpinus betulus, Fagus sylvatica, Pinus sylvestris-Acer pseudoplatanus, Pinus sylvestris-Acer platanoides-Tilia cordata-Carpinus betulus, Pinus sylvestris-Prunus serotina, Pinus sylvestris-Quercus petraea, Quercus petraea, Quercus rubra, and Robinia pseudoacacia. Within plots leaf litter $\mathrm{pH}$ ranged from 3.83 to 6.44 with an average of $5.20 \pm 0.01$ and

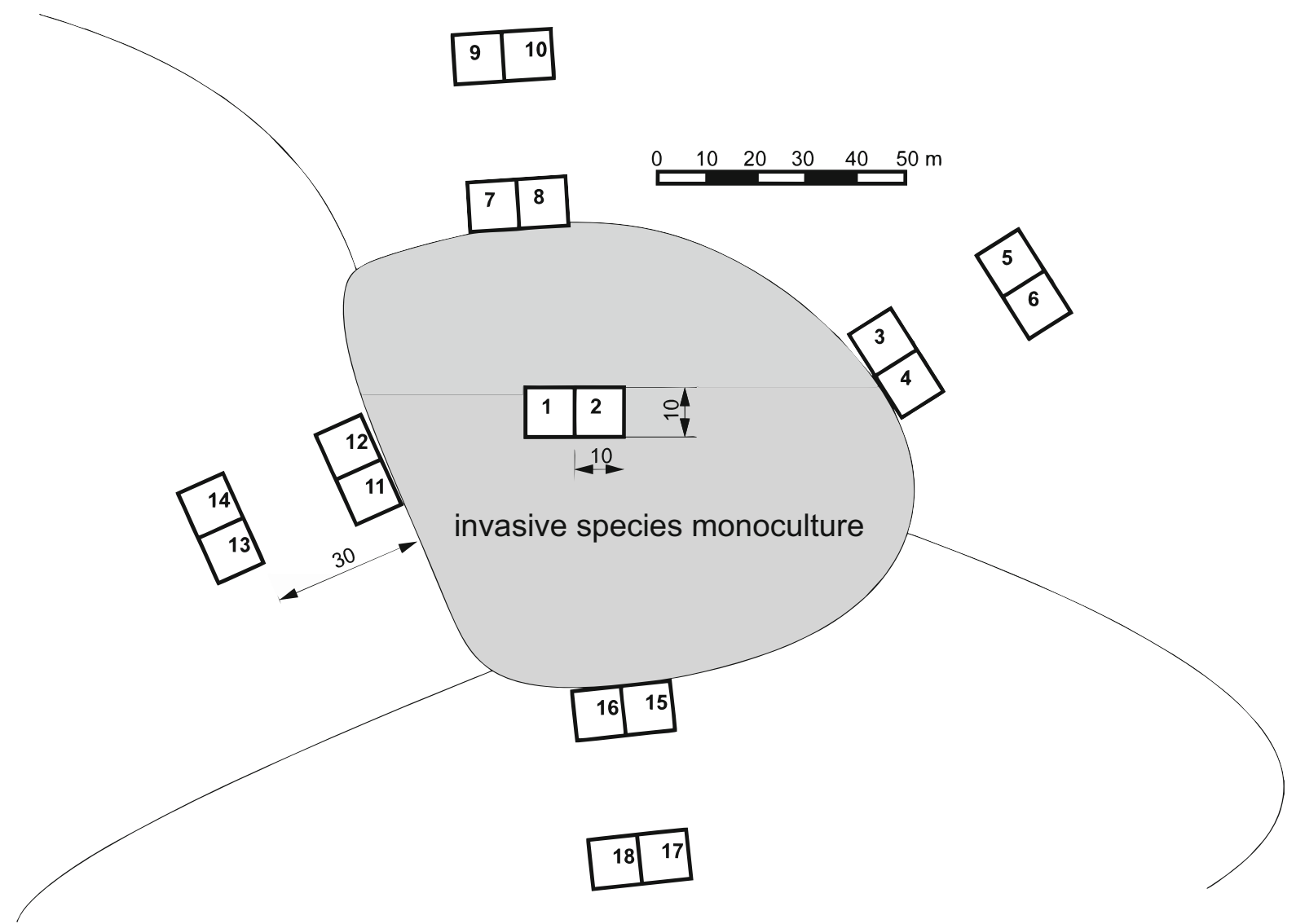

Fig. 1 Scheme for a block of experimental plots in the field. Each block $(\mathrm{n}=21)$ is a set of 18 square plots $\left(100 \mathrm{~m}^{2}\right)$, with a center in the propagule source - an invasive species monoculture or for $P$. serotina a tree stand with a dense fruiting P. serotina layer 
light availability ranged from 0.007 to 0.251 with an average of $0.044 \pm 0.001$.

\section{Data collection}

In July of 2015, 2016 and 2017 we counted the number of seedlings (defined as individuals germinated in a particular year) and saplings (defined as individuals at least one year old and with height $<0.5 \mathrm{~m}$ ) within each plot, and in 2015, 2016 and 2017 we also measured root collar diameters (RCD) and heights $(\mathrm{H})$ of the seedlings and saplings. This data was used for biomass calculation for each year. We treated sprouts (i.e. specimens generated through vegetative reproduction from root suckers) as saplings, due to their usually larger dimensions and connectivity with their parental organism. After measuring 28,703 seedlings, we found that height measurements of up to 30 seedlings is enough to cover the range of variance in seedling heights, and thus in 2017 for that age class we measured up to 30 heights, due to high seedling densities in some study plots (in cases of 50 plots with $P$. serotina and 23 with $R$. pseudoacacia). For these plots we used mean dimensions of seedlings to calculate individual biomass and multiplied by seedling density to produce biomass of seedlings. This did not affect calculated biomass, due to low SE of the mean for seedling total biomass (TB). In total we measured 39,664 plants. During these inventories we also investigated vegetation species composition and abundance using the Braun-Blanquet method: for each plant species in the understory (forest layer up to $50 \mathrm{~cm}$ ) we assigned one of nine cover degrees in an alphanumeric scale. Moreover, in 2015 we assessed tree stand structures for study plots within larger (0.02-0.20 ha) plots, where diameter at breast height was measured for all trees and basal area (BA) was computed for each tree species.

In August 2016 we measured canopy openness index (diffuse non-interceptance; DIFN) in each plot, using an LAI-2200 plant canopy analyzer (Li-Cor Inc., Lincoln, NE, USA). For each plot we recorded four series of ten samples, using the methodology of Machado and Reich (1999). We chose August for the measurement time, as our previous studies showed that canopy openness was lowest during this month due to maximal canopy foliage development (Knight et al. 2008); thus, we accounted for the minimal light availability within our model. Light was an important predictor in previous invasion ecology studies (e.g. Knight et al. 2008; Jagodziński et al. 2018a). To account for rates of nutrient cycling and acidity we used litter mass and $\mathrm{pH}$. We decided to use litter predictors instead of soil, as litter is the main source of nutrients for the uppermost soil horizons. However, these predictors are only proxies for direct measurements of soil predictors. Litter was sampled in March 2017, when its amount was stabilized after winter. For each pair of plots we collected four samples from circular plots $\left(0.16 \mathrm{~m}^{2}\right)$. Woody debris with diameter $>1 \mathrm{~cm}$ was excluded from litter samples. Litter samples were dried in an oven at $65^{\circ} \mathrm{C}$ to constant mass and visually divided into two parts: recognizable and decomposed (unrecognizable) parts of litter. Next we weighed both samples using a balance with an accuracy of $1 \mathrm{~g}$ and determined proportion of the decomposed part of litter, which is usually higher in tree stands with low rates of organic matter cycling. Litter $\mathrm{pH}$ was assessed using a $\mathrm{pH}$-meter in distilled water solution after $24 \mathrm{~h}$.

To assess biomass of natural regeneration we destructively sampled 647 trees in July 2017 (Table S1). We used biomass as a measure of ecological success, because this predictor increases with both increasing density and dimensions, reflecting space filled by the species, and is also claimed to be a good measure of plant fitness (Younginger et al. 2017). For each pair of plots we surveyed an area with radius of $5 \mathrm{~m}$ around the plot borders and randomly selected up to five specimens for each species, according to available number of specimens and species densities within plots. We excluded heavily damaged and browsed plants, unless there were no alternative specimens in the area examined. This accounted for the joint effects of lower growth and resistance to herbivory in suboptimal sites. This approach also resulted in unequal numbers of sample trees per species: 356 sample trees of $P$. serotina $(195$ seedlings and 161 saplings), 133 of $Q$. rubra (72 seedlings and 61 saplings) and 158 of $R$. pseudoacacia (94 seedlings and 64 saplings). These unequal numbers resulted from unequal distributions of natural regeneration of the species studied within the study plots. Each sample tree was dug up, cleaned and divided into roots, stems with branches and leaves. We excluded acorns which were still attached to $Q$. rubra and $Q$. petraea seedlings from the total biomass (TB). For each sample tree we also measured RCD and H. 
Within the sampled tree dataset we found that 14 of $161(8.7 \%)$ P. serotina and 23 of $64(35.9 \%) R$. pseudoacacia saplings had root suckers, and for these sample trees we did not include belowground biomass, because their root system was part of the parental plant. However, despite this belowground biomass exclusion, we included them in the dataset because their aboveground biomass also contributed to the understory. We did not assess whether each of the plants that were not destructively sampled were vegetative or generative reproduction, to not influence their survival probability, which would undermine future usage of permanent plots.

Data analysis

All analyses were conducted using R software (R Core Team 2017). Prior to modelling datasets were centered, scaled and processed using Yeo-Johnson power transformations (Yeo and Johnson 2000) to stabilize variance, increase normality of distributions and overcome problems with different magnitudes of variables. This preprocessing was carried out using the caret::preProcess() function (Kuhn 2008). As our data has hierarchical structure, which may influence model outcomes (Roberts et al. 2017), we decided to assess potential blocking effects of the plot layout in the field. We checked whether the most important predictors describing resource availability-DIFN, litter mass and $\mathrm{pH}$ - showed clustering related to the blocks. We performed k-means clustering using six clusters (the optimal cluster number was estimated by the elbow method) using the stats::kmeans() function. Then we compared clusters with principal components analysis of centered and scaled values of the analyzed predictors and we visually inspected how the blocks were arranged within the ordination space (Figure S1). This analysis showed that potential blocking effects were related to the availability of resources rather than spatial proximity, and therefore for further analyses we decided to use modelling methods that did not account for the arrangement of blocks.

To predict TB of the species studied we used allometric equations, following Jagodziński et al. (2018a, b). Because our sample trees were collected within plots and blocks, they differed in dimensions and plot design expressed different resource availabilities rather than spatial structures (Figure S1). We quantified how much variance in TB was explained by dimensions and by resource availability predictors (litter mass, $\mathrm{pH}$ and DIFN) using boosted regression tree models (Elith et al. 2008). Influence of the latter predictor explained $10.2,9.0$ and $0.0 \%$ for $Q$. rubra, P. serotina and $R$. pseudoacacia, respectively, thus we decided to use the simplest approach-linear and non-linear allometric models. From ten formulas of allometric relationships used by Jagodziński et al. (2018a, b) we chose the model with the lowest AIC (Table S2). For P. serotina $\mathrm{TB}=0.03917 \times \mathrm{DRC}^{2.13334} \times \mathrm{H}^{0.49044} \quad$ (with mean error of 0.059 and $\mathrm{R}^{2}=0.880$ ), for $Q$. rubra $\mathrm{TB}=$ $0.004935 \times \mathrm{DRC}^{1.672448} \times \mathrm{H}^{1.371159}$ (with mean error of 0.067 and $\mathrm{R}^{2}=0.852$ ) and for $R$. pseudoacacia $\mathrm{TB}=0.004002 \times \mathrm{DRC}^{1.078374} \times \mathrm{H}^{1.203052}$ (with mean error of 0.013 and $\mathrm{R}^{2}=0.955$ ).

We analyzed vegetation patterns using functional traits provided by BiolFlor (Klotz et al. 2002), BryoAtt (Hill et al. 2007) and LEDA (Kleyer et al. 2008) databases, as well as ecological indicator values (EIV; Ellenberg and Leuschner 2010). For each plant species we extracted EIV for light, fertility, soil reaction, moisture, continentality and temperature, as well as canopy height, leaf mass, size, dry matter content, specific leaf area (SLA), growth form, seed mass and number per shoot, reproduction mode and Grime's (Grime 2006) life strategy (Table S3). These traits were used for calculation of functional diversity components: functional dispersion (FDis), functional divergence (FDiv), functional evenness (FEve) and functional richness (FRic). These components describe distribution of species' functional traits for each sampled plant community within a hypervolume of traits (Mason et al. 2005; Laliberté and Legendre 2010; Pla et al. 2011), indicating prevalence of processes shaping species composition of the community. High values of FDiv indicate numerous functional ways of resource acquisition, which is associated with higher competition, similar to high FEve, indicating lack of one dominant type of resource acquisition. High values of FRic and FDis indicate numerous functional plant types and low level of habitat filtering in the plant community (Kotowski et al. 2010; Hedberg et al. 2014; Dyderski et al. 2016; but see Kraft et al. 2015). Moreover, to characterize dominant plant strategies, we used three communityweighted mean (CWM) values of functional traits: SLA, height and seed mass, according to the LHS 
concept (Westoby 1998) and global spectrum of plant functions (Díaz et al. 2016). All functional diversity components and CWMs used for analyses of particular invasive species studied were calculated excluding that species, to avoid circular reasoning and biased variable importance, connected with different functional traits (Thomsen et al. 2016), for example, overestimated importance of seed mass CWM for $Q$. rubra, with its high value of this trait. Usage of functional diversity components allows conclusions about impact of plant community on the species of interest (Kurokawa et al. 2010; D'Astous et al. 2013; Jagodziński et al. 2017; Czortek et al. 2018).

In our dataset some predictors were correlated, because they reflect different aspects of phenomena studied. For example, propagule source presence/ absence and basal area correlation coefficient $r$ was 0.56 for $P$. serotina, but the former predictor reflected mere presence of seed source and the latter predictor reflected its quantity. For that reason and for better ecological interpretation we decided not to exclude them from analyses. Only three pairs of predictors had correlation coefficients (r) $>0.6$ - species richness and Shannon's index (0.73), FRich and species richness (0.65) and litter mass and proportion of decomposed part of litter (0.6). To ensure that our results were not biased by year-to-year dynamics, in modelling we used averaged vegetation predictors and biomasses for each plot. This averaging was also necessary as some predictors, e.g. tree stand and litter predictors as well as DIFN, were measured only once and combining them with more variable predictors would bias their importance. To assess influence of factors describing resource availability, propagule pressure and competitors we used the random forest method (RF; Breiman 2001), trained using the caret::train() function (Kuhn 2008). We chose RF due to its good performance in cases of collinear variables, non-normal distributions of predictors and high predictive power. As an alternative, we also tested boosted regression trees (Elith et al. 2008), which showed lower fitness-lower coefficients of determination and higher RMSE (Fig. S2). Due to differences in survival, we assessed biomass of seedlings, saplings and total natural regeneration of each species separately. For each RF model we produced two results/outputs -importance of variables and partial dependence plots. Variable importance is expressed by mean decrease in accuracy (\%IncMSE), which is a percentage increase of mean squared error of the result when the considered variable was permuted. Partial dependence plots express impact of a single variable on a response when all remaining predictors within a given model are constant.

\section{Results}

Biomass of natural regeneration

Natural regeneration of R. pseudoacacia, Q. rubra and $P$. serotina, was found in 165,194 and 239 plots, respectively. Biomass of natural regeneration for these three species within study plots ranged from 0.00 to $257.19 \mathrm{~kg} \mathrm{ha}^{-1}$, with an average of $1.52 \pm$ $0.36 \mathrm{~kg} \mathrm{ha}^{-1}$ (Fig. 2). However, medians for each species seedlings and saplings did not exceed $1 \mathrm{~kg} \mathrm{ha}^{-1}$. For $P$. serotina total biomass ranged from 0 to $9.61 \mathrm{~kg} \mathrm{ha}^{-1}$, with an average of $0.81 \pm$ $0.09 \mathrm{~kg} \mathrm{ha}^{-1}$; for $Q$. rubra from 0.00 to $257.19 \mathrm{~kg} \mathrm{ha}^{-1}$, with an average of $1.04 \pm$ $0.69 \mathrm{~kg} \mathrm{ha}^{-1}$ and for $R$. pseudoacacia from 0.00 to $1.81 \mathrm{~kg} \mathrm{ha}^{-1}$, with an average of $0.07 \pm$ $0.01 \mathrm{~kg} \mathrm{ha}^{-1}$. Mean proportions of total seedling biomass within plots were $30.7 \pm 2.3,29.8 \pm 2.7$ and $48.7 \pm 3.2 \%$ for P. serotina, $Q$. rubra and $R$. pseudoacacia, respectively.

\section{Hierarchy of predictors}

RF models explained from $56.5 \%$ (R. pseudoacacia seedlings) to $78.3 \%$ of variance ( $P$. serotina total) in the biomass of the species studied and included from 3 to 10 predictors (Table 1). Two of the most important predictors for each species and biomass type were presence of parental trees in the plot or in the nearest neighborhood and basal area of parental trees in the tree stand (Table 1). Exceptions were saplings and total biomass of $Q$. rubra, for which the second most important predictor was litter mass. Nevertheless, \%IncMSE connected with nearest presence of propagule source ranged from 30.2 to $50.2 \%$. Basal area of parental trees had the highest importance for $P$. serotina and the lowest for $Q$. rubra. This predictor also was more important for seedlings than saplings. The second group of predictors was connected with leaf litter predictors. The most important of them was litter mass, however its importance for $R$. 


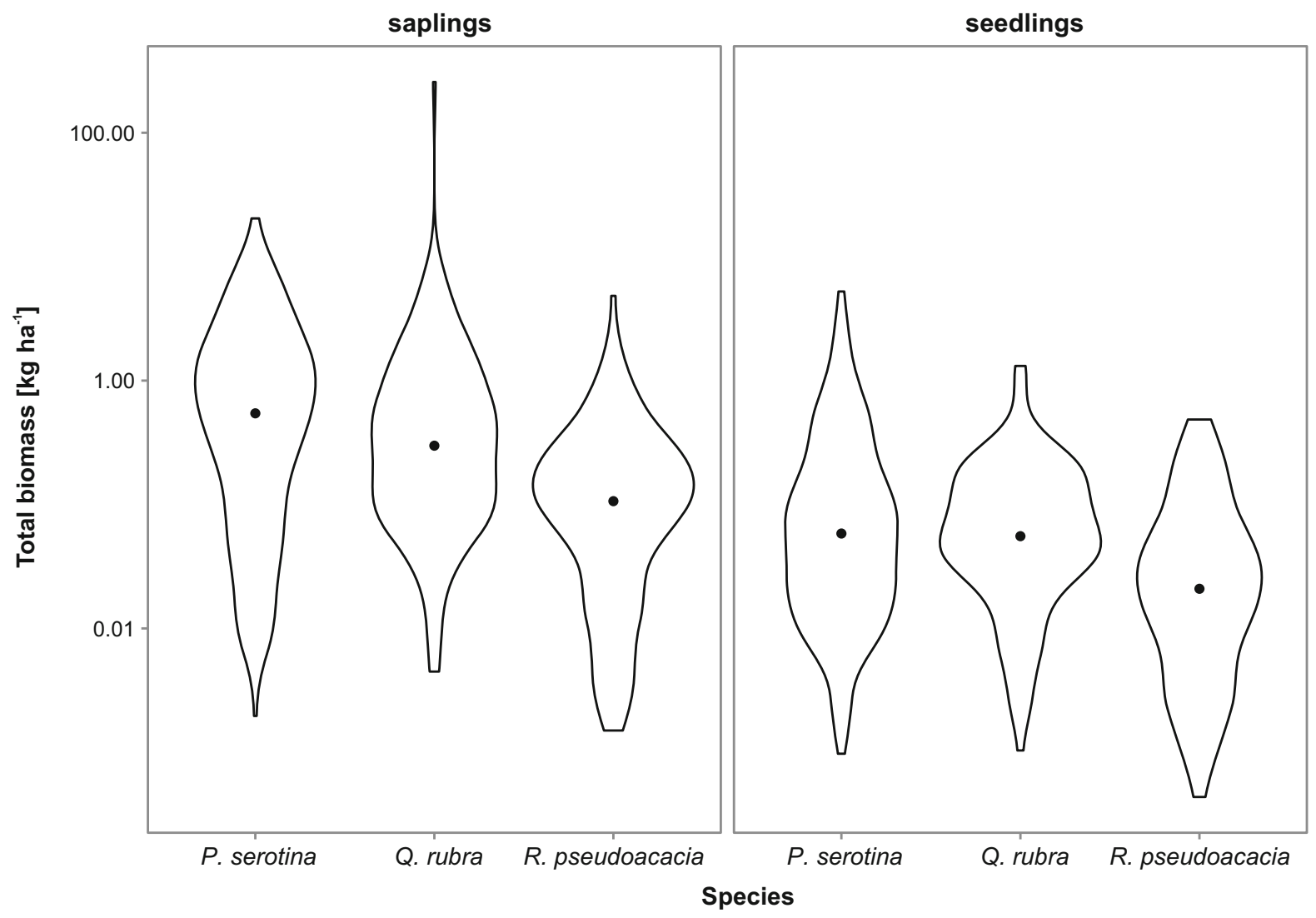

Fig. 2 Distributions of sapling and seedling biomass for each species within study plots $(n=372)$. Distributions are shown by violin plots - the wider the shape is, the more frequent the

pseudoacacia was lower than for the other species. Leaf litter predictors were the most important for $P$. serotina, especially for seedlings. Litter $\mathrm{pH}$ usually had lower importance than litter mass, with the exception of total $R$. pseudoacacia biomass. Fraction of decomposed material in litter was included only in the model of total P. serotina biomass. Light availability, expressed by DIFN, had the highest importance for R. pseudoacacia and the lowest for Q. rubra. Among predictors expressing tree stand features, number of tree species had higher importance than tree stand BA. Tree stand species richness was most important for R. pseudoacacia, and least for Q. rubra. Tree stand BA had the highest importance for $R$. pseudoacacia. Among understory predictors the highest importance was species richness, which had the highest importance for $P$. serotina and $Q$. rubra. Its importance was higher for saplings and total biomass than for seedlings. Understory species diversity, particular value of the variable is. Dots inside the violins indicate medians. Note log-transformation of y-axis

expressed by Shannon's index had the highest importance for $R$. pseudoacacia. CWMs describing functional traits of understory had the lowest importance for $Q$. rubra and the highest for $P$. serotina. For an average, the most important CWM was plant height. For $Q$. rubra the most important was CWM of SLA. Functional diversity indices was the group of predictors with the lowest importance. However, among species FRic, FDis and FEve were most important for $P$. serotina and FDiv for $Q$. rubra. In most cases values of importance of functional diversity components were higher for saplings than seedlings.

Impact of predictors on studied species biomass

Partial dependence plots (Fig. 3) revealed that response of saplings to presence of propagule source in the vicinity was lower than response of seedlings. All species biomasses increased with proportion of 


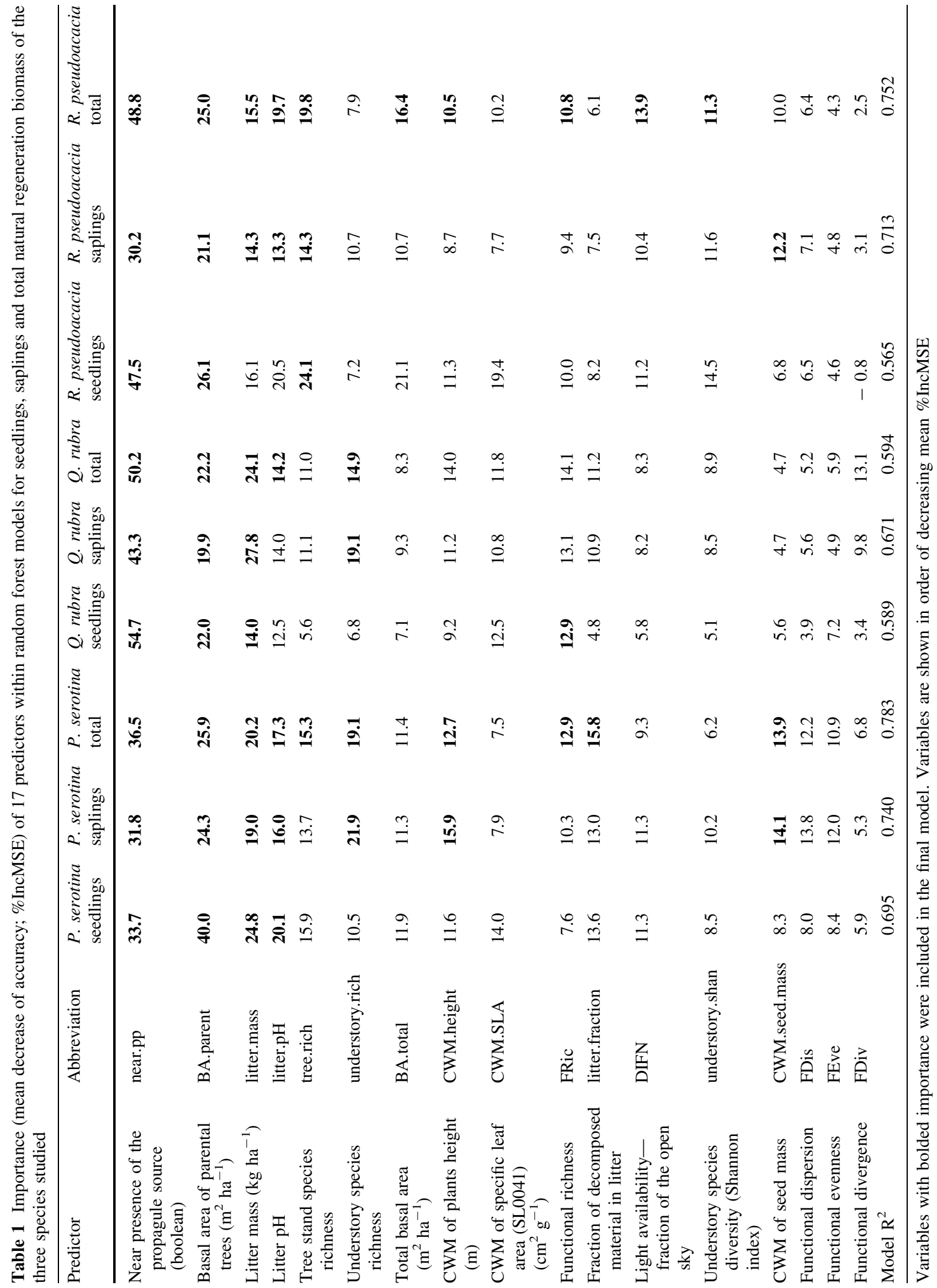




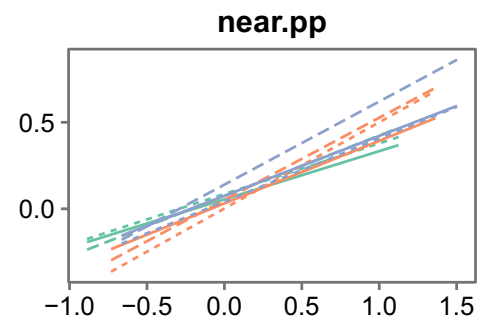

litter.pH

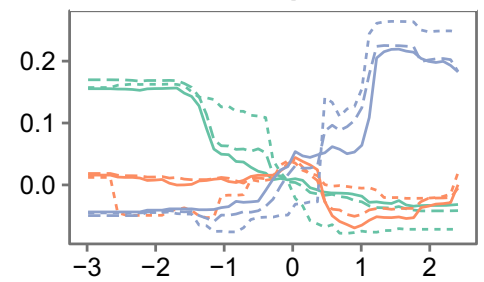

BA.total

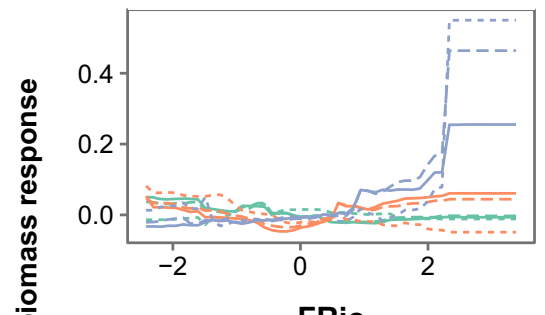

FRic

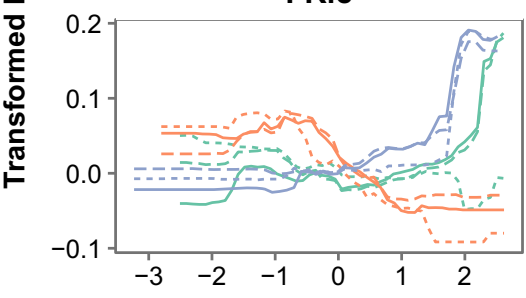

understory.shan

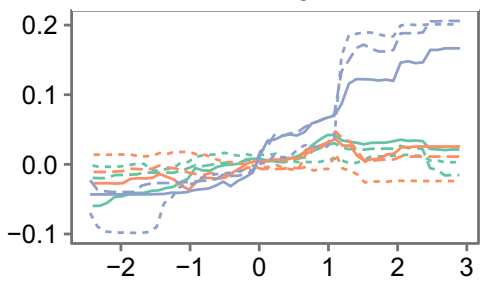

FEve

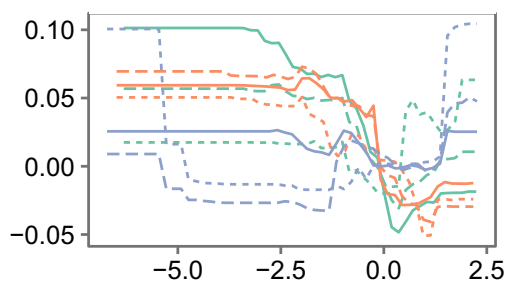

BA.parent

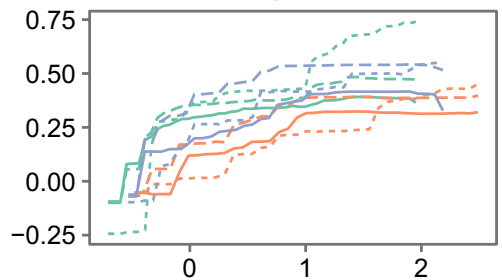

tree.rich

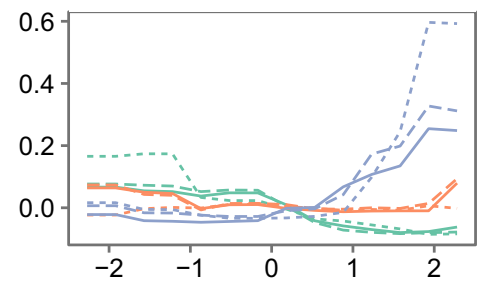

CWM.height

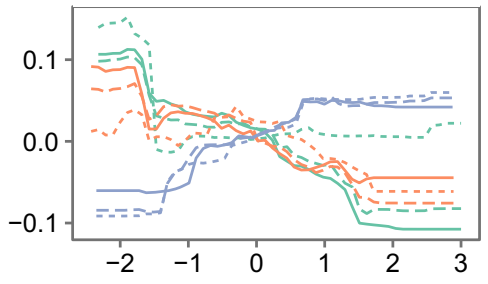

litter.fraction

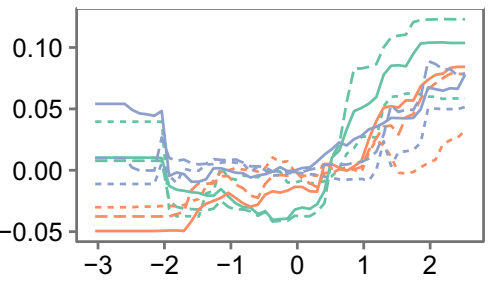

CWM.seed.mass

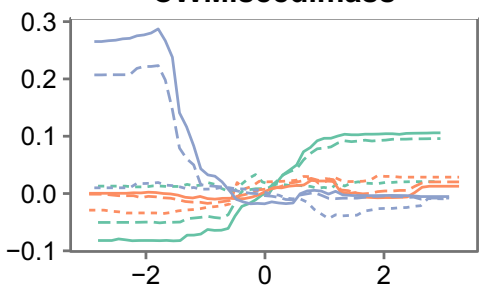

FDiv

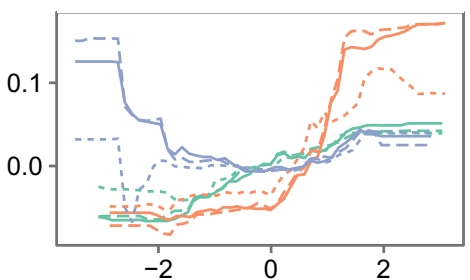

litter.mass

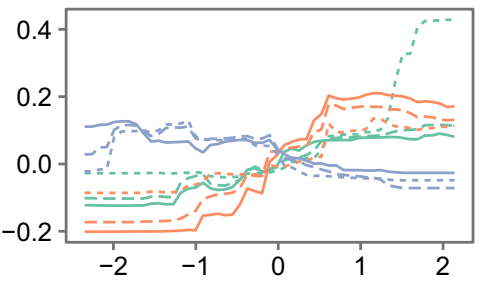

understory.rich

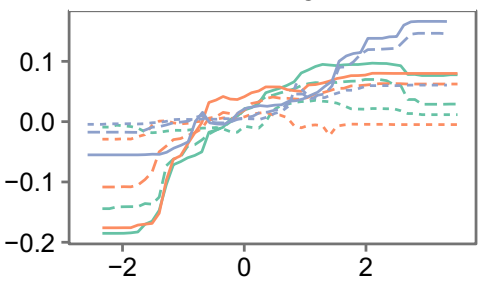

CWM.SLA
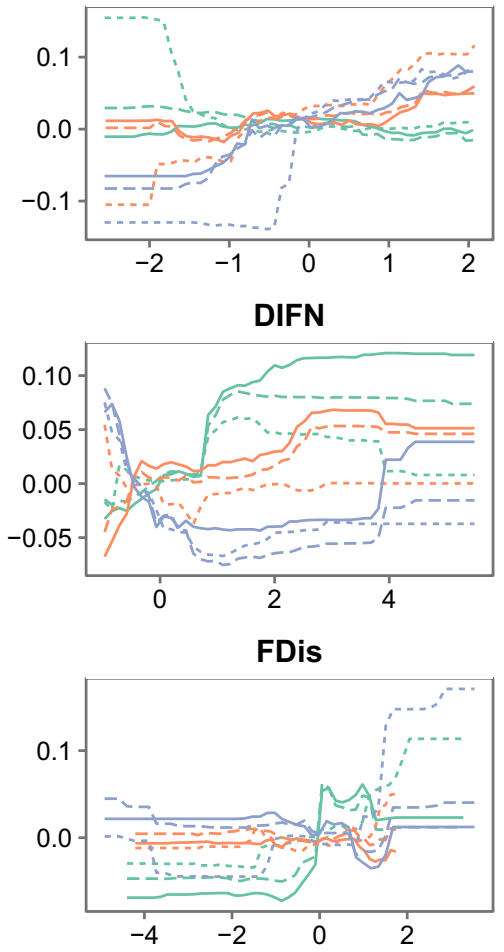

P. serotina

Q. rubra

R. pseudoacacia

Saplings

...- Seedlings

--- Total 
४Fig. 3 Partial dependence plots showing impacts of particular variables (abbreviations and predictors importance in Table 1) on response functions of biomass for biomass types and species studied, when all remaining predictors were constant. Response and variables were centered, scaled and processed by YeoJohnson power transformation

parent trees in basal area, up to thresholds at which response curves reached plateaus. This threshold was reached first by $Q$. rubra, then by $R$. pseudoacacia and finally by $P$. serotina. However, the response curve was steepest for $R$. pseudoacacia total biomass. Increasing litter mass was associated with increasing biomass of $P$. serotina and $Q$. rubra and decreasing biomass of $R$. pseudoacacia. Only seedlings of $P$. serotina showed a steeper response curve at the higher range of litter mass than saplings and total biomass. Responses to DIFN differed among species studied: biomasses of $P$. serotina and $Q$. rubra increased with increasing DIFN, however biomass of $P$. serotina seedlings in the highest fraction of DIFN range decreased. Biomass of $Q$. rubra decreased with increasing tree stand species richness and biomasses of $P$. serotina and $R$. pseudoacacia increased. The positive response of $R$. pseudoacacia was steeper in the highest range of tree stand species richness, especially for seedlings. This species showed a similar response to tree stand BA. The biomasses of all species studied increased with increasing understory species richness, however in the case of seedlings the size effect was minimal.

\section{Discussion}

Model limitations

Despite the high number of predictors studied, some of them are only proxies for direct measurements. For example, litter traits are surrogates for soil chemistry, which is crucial for plant growth (e.g. Mueller et al. 2012; Aerts et al. 2017). We also did not divide regeneration into generative and vegetative specimens. Another potential drawback may result from low variability of climatic conditions, which drive the distributions of species studied at large spatial scales (Dyderski et al. 2018). Resource availability gradients do not account for water availability, as we did not sample dry and wet habitat types, due to their relatively low abundance, thus soil moisture effects were not studied. Nevertheless, the large number of study plots and temporal variation increased robustness of the conclusions.

Impact of propagule pressure on species invasion success

Almost all models showed that propagule pressure was the most important influence on invasion success, expressed by biomass of natural regeneration. Propagule source presence and propagule quantity both contribute to increasing propagule pressure, however, they each account for a different aspect of propagule availability. Different species reacted in a different way to presence and quantity: Q. rubra depended more on propagule vicinity than $R$. pseudoacacia and $P$. serotina was the least dependent among species studied. However, P. serotina had the highest importance of propagule quantity, similar to other studies (e.g. Chabrerie et al. 2008; Vanhellemont et al. 2009; Terwei et al. 2013). The important role of propagule pressure has been confirmed for numerous woody species (e.g. Pyšek et al. 2009; Sinclair and Arnott 2015; Rodríguez et al. 2017), and also for the species studied (e.g. Vanhellemont et al. 2009; Woziwoda et al. 2014; Jagodziński et al. 2015). Ecological success of $P$. serotina and $Q$. rubra, expressed either as seedling density (Pairon et al. 2006; Riepšas and Straigyté 2008; Jagodziński et al. 2015) or biomass (Jagodziński et al. 2018a) decreased with distance from propagule source. Although $Q$. rubra acorns are not preferred by birds (Myczko et al. 2014; Bieberich et al. 2016), its maximum dispersal distance referred to in the literature is higher than that of $P$. serotina $(1500$ vs. $600 \mathrm{~m}$ ), which is eaten by numerous bird species (Bartkowiak 1970; Deckers et al. 2008). The high importance of fruiting tree BA may also reflect the fact that ca. $80 \%$ of fruits fall beneath the crowns of $P$. serotina and birds may disperse only $20 \%$ of them (Pairon et al. 2006). Lower importance of propagule source BA for $Q$. rubra may suggest better dispersal of this species, e.g. by rodents (Bieberich et al. 2016). Another explanation may result from with high seed mass and stored carbohydrates allowing growth in unsuitable conditions (Ziegenhagen and Kausch 1995). Under this assumption, even a single tree in the stand may produce an effective number of seedlings, and due to their low densities, may result 
in biomass similar to the other species despite the low contribution of $Q$. rubra to tree stand BA.

Propagule pressure increases the probability of alien species establishment in the plant community (Lonsdale 1999; Lockwood et al. 2005; Vanhellemont et al. 2009). For that reason plots with lower availability of seeds or sprouts are less invasible than those with higher availability. Due to probability of vegetative reproduction, effects of these variables may be biased, as the species studied are able to sprout (Closset-Kopp et al. 2007; Vítková et al. 2017). Although $10-50 \%$ of $P$. serotina natural regeneration may result from vegetative reproduction (ClossetKopp et al. 2007), our study reports a fraction (8.7\%) similar to our previous study in Rogów Arboretum (Jagodziński et al. 2015). For R. pseudoacacia it was $35.9 \%$, but due to young age of fruiting (Burns and Honkala 1990), there were no differences between presence of fruiting and sprouting trees in the vicinity of the plots. The high advantage of $R$. pseudoacacia in plots with presence of propagule source may also result from its capacity for nitrogen fixation, which fertilizes the soil (Rice et al. 2004; Cierjacks et al. 2013).

Impact of resource availability on studied species biomass

The most important factors related to availability of resources were those connected with leaf litter. These predictors were most important for $P$. serotina. However, the highest \%IncMSE in this study was for litter mass as a predictor of $Q$. rubra saplings, and the highest effect size was for seedlings. The presence of Q. rubra in the overstory usually maintains a thick layer of leaf litter, due to its low decomposition rate (Horodecki and Jagodziński 2017). Thus, in this particular case its effect cannot be clearly separated. Nevertheless, both species showed similar tendencies for litter $\mathrm{pH}$ - their biomass decreased with increasing litter $\mathrm{pH}$, which is an indicator of higher fertility. Both $P$. serotina and $Q$. rubra have been reported from fertile deciduous forests (Chmura 2004, 2013; Woziwoda et al. 2014; Dyderski et al. 2015; Jagodziński et al. 2015). P. serotina was claimed to prefer the poor and medium fertility sites of coniferous forests, and the species was planted there as a soil improver (Muys et al. 1992; Starfinger et al. 2003), but also reached high densities on habitats of fertile deciduous forests
(Jagodziński et al. 2015). Our study confirmed earlier observations that $P$. serotina reaches higher ecological success in less fertile and more acidic plots (Zerbe and Wirth 2006; Chabrerie et al. 2008; Knight et al. 2008; Halarewicz 2012; Terwei et al. 2016). In contrast, $R$. pseudoacacia reached the highest biomass in plots with low litter mass, low proportion of decomposed material and high $\mathrm{pH}$. This indicated that although $R$. pseudoacacia may occur in less fertile sites, it has the highest growth potential in the most fertile habitats. For that reason this species effectively invades riparian forests (e.g. Terwei et al. 2013; Dyderski et al. 2015; Marozas et al. 2015).

One of the most surprising results was low importance of light availability for the majority of species studied, in contrast with other studies indicating higher importance of light availability on invasion success (e.g. Knight et al. 2008; Paquette et al. 2012; Rodríguez et al. 2017). The relatively low light requirements shown by $R$. pseudoacacia were opposite to other studies (Groninger et al. 1997; Cierjacks et al. 2013). However, due to relatively high proportion of seedlings in the biomass, which was highest in the stands with lowest light availability, it may be an effect of low competition within the understory. Nevertheless, seedling survival is low (Dyderski unpubl.). Another important factor is high proportion of sprouts, which may be supplied with nutrients by parental trees, and partially independent of light availability. Groninger et al. (1997) used only trees obtained from generative reproduction, thus our results are not comparable. However, in plots with high light availability $R$. pseudoacacia also reached high biomass. Dominance of propagule pressure over invasibility may be connected with their interaction, conceptualized by Davis et al. (2005), who elaborated a model showing how propagule pressure may modify invasibility, with the two variables working together to produce 'invasion pressure'.

Impact of interactions with overstory and understory on biomass

Interactions with other members of plant communities have been claimed to be drivers of invasibility from the beginning of invasion ecology, when Elton (1958) formulated the hypothesis of biotic resistance. This concept assumed that higher species richness in plant communities may decrease invasibility. This concept 
was recently confirmed for small plots (Brown and Peet 2003; Parker et al. 2010; Iannone et al. 2016), however at larger spatial scales recent studies confirmed that relationships between species richness of native and alien species or invader ecological success (expressed as abundance or density) are positive (Lonsdale 1999; Stohlgren et al. 1999, 2006; Knight et al. 2008; Dyderski et al. 2015, but see Parker et al. 2010). Increasing ecological success of the invasive species studied here in plots with higher species richness confirms this theory. Understory species richness was most important for $P$. serotina and $Q$. rubra saplings and total biomass, but not for seedlings. This may result from the effects of seed storage, allowing supplies of carbohydrates to seedlings which are independent of competition. The species with the lowest seed mass-R. pseudoacacia-did not show a similar response.

CWM of seed mass had the highest significance for $P$. serotina and $R$. pseudoacacia saplings. The biomass of $P$. serotina increased with increasing seed mass CWM. This may be driven by frequently cooccurring Quercus petraea and Q. rubra with high seed mass at a similar ecological scale, but also may reflect bird-mediated dispersal (Pairon et al. 2006; Deckers et al. 2008; Kurek et al. 2015; Dylewski et al. 2017). Terwei et al. (2016) interpreted a similar relationship obtained in floodplain forest as evidence for $P$. serotina shade tolerance, which has not been confirmed in our study. Biomass of $R$. pseudoacacia decreased with increasing CWM of seed mass, which may reflect its ruderal character and preference for disturbed sites (Cierjacks et al. 2013; Vítková et al. 2017), as low seed mass is connected with disturbance tolerance (Westoby 1998). P. serotina responded negatively to height CWM, which shows its negative response to understory competition. Similarly Terwei et al. (2013) found a negative relationship between density of $P$. serotina and herb layer cover.

Differences between studied species

and management implications

According to our results, management of species studied should primarily focus on removing propagule sources. If these species are planted according to their commercial value (Woziwoda et al. 2014) or ecosystem services (Vítková et al. 2017), invasion management should be focused on plant communities in the neighborhoods of plantations by shaping conditions not supporting the spread of invaders, e.g. by limiting light availability, planting competing native species or removing emerging saplings or juvenile specimens. Introduction of these best management practices for invasive woody species into forestry is crucial for limiting further invasion of these species (Brundu and Richardson 2016).

Acknowledgements The study was financed by National Science Centre, Poland, under the project no. 2015/19/N/NZ8/ 03822 entitled: 'Ecophysiological and ecological determinants of invasiveness of trees and shrubs with the examples of Padus serotina, Quercus rubra and Robinia pseudoacacia'. We are grateful to Dr. Lee E. Frelich (Department of Forest Resources, University of Minnesota, USA) for linguistic revision of the manuscript. We are thankful to two anonymous Reviewers and prof. David M. Richardson for valuable remarks which improved the previous version of the manuscript.

Open Access This article is distributed under the terms of the Creative Commons Attribution 4.0 International License (http:// creativecommons.org/licenses/by/4.0/), which permits unrestricted use, distribution, and reproduction in any medium, provided you give appropriate credit to the original author(s) and the source, provide a link to the Creative Commons license, and indicate if changes were made.

\section{References}

Aerts R, Ewald M, Nicolas M et al (2017) Invasion by the alien tree Prunus serotina alters ecosystem functions in a temperate deciduous forest. Front Plant Sci 8:179. https://doi. org/10.3389/fpls.2017.00179

Aslan CE, Rejmánek M, Klinger R (2012) Combining efficient methods to detect spread of woody invaders in urban-rural matrix landscapes: an exploration using two species of Oleaceae. J Appl Ecol 49:331-338. https://doi.org/10. 1111/j.1365-2664.2011.02097.x

Baraloto C, Goldberg DE, Bonal D (2005) Performance tradeoffs among tropical tree seedlings in contrasting microhabitats. Ecology 86:2461-2472. https://doi.org/10.1890/ 04-1956

Bartkowiak S (1970) Ornitochoria rodzimych i obcych gatunków drzew i krzewów. Arbor Kórn 15:237-261

Beckage B, Lavine M, Clark JS (2005) Survival of tree seedlings across space and time: estimates from long-term count data. J Ecol 93:1177-1184. https://doi.org/10.1111/j.13652745.2005.01053.x

Bieberich J, Lauerer M, Aas G (2016) Acorns of introduced Quercus rubra are neglected by European Jay but spread by mice. Ann For Res 59:249-258. https://doi.org/10. 15287/afr.2016.522

Bonilla NO, Pringle EG (2015) Contagious seed dispersal and the spread of avian-dispersed exotic plants. Biol Invasions 
17:3409-3418. https://doi.org/10.1007/s10530-015-09664

Breiman L (2001) Random forests. Mach Learn 45:5-32. https://doi.org/10.1023/A:1010933404324

Brown RL, Peet RK (2003) Diversity and invasibility of southern Appalachian plant communities. Ecology 84:32-39. https://doi.org/10.1890/0012-9658(2003)084

Brundu G, Richardson DM (2016) Planted forests and invasive alien trees in Europe: a Code for managing existing and future plantings to mitigate the risk of negative impacts from invasions. NeoBiota 30:5-47. https://doi.org/10. 3897/neobiota.30.7015

Burns RM, Honkala BH (1990) Silvics of north America. U.S. Dept. of Agriculture Forest Service, Washington, DC

Chabrerie O, Verheyen K, Saguez R, Decocq G (2008) Disentangling relationships between habitat conditions, disturbance history, plant diversity, and American black cherry (Prunus serotina Ehrh.) invasion in a European temperate forest. Divers Distrib 14:204-212. https://doi.org/10.1111/ j.1472-4642.2007.00453.x

Chmura D (2004) Penetration and naturalisation of invasive alien plant species (neophytes) in woodlands of the Silesian Upland (southern Poland). Nat Conserv 60:3-11

Chmura D (2013) Impact of alien tree species Quercus rubra L. on understorey environment and flora: a study of the Silesian Upland (southern Poland). Pol J Ecol 61:431-442

Chmura D, Sierka E (2005) The occurrence of invasive alien plant species in selected forest nature reserves in southern Poland as a conservation problem. Nat Conserv 62:3-11

Chmura D, Sierka E (2007) The invasibility of deciduous forest communities after disturbance: a case study of Carex brizoides and Impatiens parviflora invasion. For Ecol Manag 242:487-495. https://doi.org/10.1016/j.foreco.2007.01. 083

Chytrý M, Maskell LC, Pino J et al (2008) Habitat invasions by alien plants: a quantitative comparison among Mediterranean, subcontinental and oceanic regions of Europe. J Appl Ecol 45:448-458. https://doi.org/10.1111/j.13652664.2007.01398.x

Cierjacks A, Kowarik I, Joshi J et al (2013) Biological flora of the British Isles: Robinia pseudoacacia. J Ecol 101:1623-1640. https://doi.org/10.1111/1365-2745.12162

Closset-Kopp D, Chabrerie O, Valentin B et al (2007) When Oskar meets Alice: does a lack of trade-off in r/K-strategies make Prunus serotina a successful invader of European forests? For Ecol Manag 247:120-130. https://doi.org/10. 1016/j.foreco.2007.04.023

Core Team R (2017) R: a language and environment for statistical computing. R Foundation for Statistical Computing, Vienna

Cornelissen JHC, Lavorel S, Garnier E et al (2003) A handbook of protocols for standardised and easy measurement of plant functional traits worldwide. Aust J Bot 51:335-380. https://doi.org/10.1071/BT02124

Czortek P, Delimat A, Dyderski MK et al (2018) Climate change, tourism and historical grazing influence the distribution of Carex lachenalii Schkuhr-A rare arcticalpine species in the Tatra Mts. Sci Total Environ 618:1628-1637. https://doi.org/10.1016/j.scitotenv.2017. 10.001
D’Astous A, Poulin M, Aubin I, Rochefort L (2013) Using functional diversity as an indicator of restoration success of a cut-over bog. Ecol Eng 61(Part B):519-526. https://doi. org/10.1016/j.ecoleng.2012.09.002

Davis MA, Grime JP, Thompson K (2000) Fluctuating resources in plant communities: a general theory of invasibility. J Ecol 88:528-534. https://doi.org/10.1046/j.1365-2745. 2000.00473.x

Davis MA, Thompson K, Philip Grime J (2005) Invasibility: the local mechanism driving community assembly and species diversity. Ecography 28:696-704. https://doi.org/10.1111/ j.2005.0906-7590.04205.x

Deckers B, Verheyen K, Vanhellemont M et al (2008) Impact of avian frugivores on dispersal and recruitment of the invasive Prunus serotina in an agricultural landscape. Biol Invasions 10:717-727. https://doi.org/10.1007/s10530007-9164-3

Díaz S, Kattge J, Cornelissen JHC et al (2016) The global spectrum of plant form and function. Nature 529:167-171. https://doi.org/10.1038/nature16489

Dyderski MK, Jagodziński AM (2016) Patterns of plant invasions at small spatial scale correspond with that at the whole country scale. Urban Ecosyst. https://doi.org/10. 1007/s11252-015-0524-y

Dyderski MK, Gdula AK, Jagodziński AM (2015) “The rich get richer" concept in riparian woody species-a case study of the Warta River Valley (Poznań, Poland). Urban For Urban Green 14:107-114. https://doi.org/10.1016/j.ufug.2014.12. 003

Dyderski MK, Czapiewska N, Zajdler M et al (2016) Functional diversity, succession, and human-mediated disturbances in raised bog vegetation. Sci Total Environ 562:648-657. https://doi.org/10.1016/j.scitotenv.2016.04.102

Dyderski MK, Paź S, Frelich LE, Jagodziński AM (2018) How much does climate change threaten European forest tree species distributions? Glob Change Biol 24:1150-1163. https://doi.org/10.1111/gcb.13925

Dylewski Ł, Kurek P, Wiatrowska B et al (2017) Man-made perching sites-electricity pylons accelerate fleshy-fruited plants succession in farmlands. Flora 231:51-56. https:// doi.org/10.1016/j.flora.2017.04.004

Elith J, Leathwick JR, Hastie T (2008) A working guide to boosted regression trees. J Anim Ecol 77:802-813. https:// doi.org/10.1111/j.1365-2656.2008.01390.x

Ellenberg H, Leuschner C (2010) Vegetation Mitteleuropas mit den Alpen in ökologischer, dynamischer und historischer Sicht. UTB, Stuttgart

Elton CS (1958) The ecology of invasions by animals and plants. University of Chicago Press, Chicago

Funk JL (2008) Differences in plasticity between invasive and native plants from a low resource environment. J Ecol 96:1162-1173

Gallien L, Carboni M (2017) The community ecology of invasive species: where are we and what's next? Ecography 40:335-352. https://doi.org/10.1111/ecog.02446

Gazda A, Szwagrzyk J (2016) Introduced species in Polish National Parks: distribution, abundance and management approaches. In: Krumm F, Vítková L (eds) Introduced tree species in European forests: opportunities and challenges. European Forest Institute, Freiburg, pp 168-175 
Godefroid S, Phartyal SS, Weyembergh G, Koedam N (2005) Ecological factors controlling the abundance of non-native invasive black cherry (Prunus serotina) in deciduous forest understory in Belgium. For Ecol Manag 210:91-105. https://doi.org/10.1016/j.foreco.2005.02.024

González-Muñoz N, Castro-Díez P, Godoy O (2014) Lack of superiority of invasive over co-occurring native riparian tree seedling species. Biol Invasions 16:269-281. https:// doi.org/10.1007/s10530-013-0516-x

Grime JP (2006) Plant strategies, vegetation processes, and ecosystem properties. Wiley, Hoboken

Groninger JW, Zedaker SM, Fredericksen TS (1997) Stand characteristics of inter-cropped loblolly pine and black locust. For Ecol Manag 91:221-227. https://doi.org/10. 1016/S0378-1127(96)03863-7

Halarewicz A (2012) Właściwości ekologiczne i skutki rozprzestrzeniania się czeremchy amerykańskiej Padus serotina (Ehrh.) Borkh. w wybranych fitocenozach leśnych. Wydawnictwo Uniwersytetu Przyrodniczego, Wrocław

Hedberg P, Kozub Ł, Kotowski W (2014) Functional diversity analysis helps to identify filters affecting community assembly after fen restoration by top-soil removal and hay transfer. J Nat Conserv 22:50-58. https://doi.org/10.1016/j. jnc.2013.08.004

Hill MO, Preston CD, Bosanquet SDS, Roy DB (2007) BRYOATT: attributes of British and Irish mosses, liverworts and hornworts. Centre for Ecology and Hydrology, Huntingdon

Horodecki P, Jagodziński AM (2017) Tree species effects on litter decomposition in pure stands on afforested postmining sites. For Ecol Manag 406:1-11. https://doi.org/10. 1016/j.foreco.2017.09.059

Hulme PE, Pyšek P, Pergl J et al (2014) Greater focus needed on alien plant impacts in protected areas: plant invasion impacts in protected areas. Conserv Lett 7:459-466

Iannone BV, Potter KM, Hamil K-AD et al (2016) Evidence of biotic resistance to invasions in forests of the Eastern USA. Landsc Ecol 31:85-99. https://doi.org/10.1007/s10980015-0280-7

Jagodziński AM, Dyderski MK, Rawlik M, Banaszczak P (2015) Plantation of coniferous trees modifies risk and size of Padus serotina (Ehrh.) Borkh. invasion-Evidence from a Rogów Arboretum case study. For Ecol Manag 357:84-94. https://doi.org/10.1016/j.foreco.2015.08.011

Jagodziński AM, Horodecki P, Rawlik K, Dyderski MK (2017) Do understorey or overstorey traits drive tree encroachment on a drained raised bog? Plant Biol 19:571-583. https://doi.org/10.1111/plb.12569

Jagodziński AM, Dyderski MK, Horodecki P, Rawlik K (2018a) Limited dispersal prevents Quercus rubra invasion in a 14-species common garden experiment. Divers Distrib 24:403-414. https://doi.org/10.1111/ddi.12691

Jagodziński AM, Dyderski MK, Gęsikiewicz K et al (2018b) How do tree stand parameters affect young Scots pine biomass?-Allometric equations and biomass conversion and expansion factors. For Ecol Manag 409:74-83. https:// doi.org/10.1016/j.foreco.2017.11.001

Jeschke JM (2014) General hypotheses in invasion ecology. Divers Distrib 20:1129-1134. https://doi.org/10.1111/ddi. 12258
Kleyer M, Bekker RM, Knevel IC et al (2008) The LEDA Traitbase: a database of life-history traits of the Northwest European flora. J Ecol 96:1266-1274. https://doi.org/10. 1111/j.1365-2745.2008.01430.x

Klotz S, Kühn I, Durka W (2002) BIOLFLOR-Eine Datenbank zu biologisch-ökologischen Merkmalen der Gefäßpflanzen in Deutschland. Schriftenreihe für Vegetationskunde, Bundesamt für Naturschutz, Bonn

Knight KS, Oleksyn J, Jagodzinski AM et al (2008) Overstorey tree species regulate colonization by native and exotic plants: a source of positive relationships between understorey diversity and invasibility. Divers Distrib 14:666-675. https://doi.org/10.1111/j.1472-4642.2008. 00468.x

Kotowski W, Beauchard O, Opdekamp W et al (2010) Waterlogging and canopy interact to control species recruitment in floodplains. Funct Ecol 24:918-926. https://doi.org/10. 1111/j.1365-2435.2009.01682.x

Kraft NJB, Adler PB, Godoy O et al (2015) Community assembly, coexistence and the environmental filtering metaphor. Funct Ecol 29:592-599. https://doi.org/10.1111/ 1365-2435.12345

Křivánek M, Pyšek P, Jarošík V (2006) Planting history and propagule pressure as predictors of invasion by woody species in a temperate region. Conserv Biol 20:1487-1498. https://doi.org/10.1111/j.1523-1739.2006.00477.x

Kuhn M (2008) Building predictive models in R using the caret package. J Stat Softw 28:1-26. https://doi.org/10.18637/ jss.v028.i05

Kunstler G, Falster D, Coomes DA et al (2016) Plant functional traits have globally consistent effects on competition. Nature 529:204-207. https://doi.org/10.1038/nature 16476

Kurek P, Sparks TH, Tryjanowski P (2015) Electricity pylons may be potential foci for the invasion of black cherry Prunus serotina in intensive farmland. Acta Oecol 62:40-44

Kurokawa H, Peltzer DA, Wardle DA (2010) Plant traits, leaf palatability and litter decomposability for co-occurring woody species differing in invasion status and nitrogen fixation ability. Funct Ecol 24:513-523. https://doi.org/10. 1111/j.1365-2435.2009.01676.x

Laliberté E, Legendre P (2010) A distance-based framework for measuring functional diversity from multiple traits. Ecology 91:299-305. https://doi.org/10.1890/08-2244.1

Lockwood JL, Cassey P, Blackburn T (2005) The role of propagule pressure in explaining species invasions. Trends Ecol Evol 20:223-228. https://doi.org/10.1016/j.tree.2005. 02.004

Lonsdale WM (1999) Global patterns of plant invasions and the concept of invasibility. Ecology 80:1522-1536. https://doi. org/10.1890/0012-9658(1999)080

Machado J-L, Reich PB (1999) Evaluation of several measures of canopy openness as predictors of photosynthetic photon flux density in deeply shaded conifer-dominated forest understory. Can J For Res 29:1438-1444. https://doi.org/ 10.1139/x99-102

Marozas V, Cekstere G, Laivins M, Straigyte L (2015) Comparison of neophyte communities of Robinia pseudoacacia L. and Acer negundo L. in the eastern Baltic Sea region cities of Riga and Kaunas. Urban For Urban Green 14:826-834. https://doi.org/10.1016/j.ufug.2015.08.003 
Mason NWH, Mouillot D, Lee WG, Wilson JB (2005) Functional richness, functional evenness and functional divergence: the primary components of functional diversity. Oikos 111:112-118. https://doi.org/10.1111/j.0030-1299. 2005.13886.x

Mueller KE, Eissenstat DM, Hobbie SE et al (2012) Tree species effects on coupled cycles of carbon, nitrogen, and acidity in mineral soils at a common garden experiment. Biogeochemistry 111:601-614. https://doi.org/10.1007/s10533011-9695-7

Muys B, Maddelein D, Lust N (1992) Ecology, practice and policy of black cherry (Prunus serotina Ehrh.) management in Belgium. Silva Gandav 57:28-45

Myczko Ł, Dylewski Ł, Zduniak P et al (2014) Predation and dispersal of acorns by European Jay (Garrulus glandarius) differs between a native (Pedunculate Oak Quercus robur) and an introduced oak species (Northern Red Oak Quercus rubra) in Europe. For Ecol Manag 331:35-39. https://doi. org/10.1016/j.foreco.2014.07.027

Niinemets Ü, Valladares F (2006) Tolerance to shade, drought, and waterlogging of temperate Northern Hemisphere trees and shrubs. Ecol Monogr 76:521-547. https://doi.org/10. 1890/0012-9615(2006)076

Pairon M, Jonard M, Jacquemart A-L (2006) Modeling seed dispersal of black cherry, an invasive forest tree: how microsatellites may help? Can J For Res 36:1385-1394. https://doi.org/10.1139/x06-018

Paquette A, Fontaine B, Berninger F et al (2012) Norway maple displays greater seasonal growth and phenotypic plasticity to light than native sugar maple. Tree Physiol 32:1339-1347. https://doi.org/10.1093/treephys/tps092

Parker JD, Richie LJ, Lind EM, Maloney KO (2010) Land use history alters the relationship between native and exotic plants: the rich don't always get richer. Biol Invasions 12:1557-1571. https://doi.org/10.1007/s10530-009-95683

Pierce S, Brusa G, Vagge I, Cerabolini BEL (2013) Allocating CSR plant functional types: the use of leaf economics and size traits to classify woody and herbaceous vascular plants. Funct Ecol 27:1002-1010. https://doi.org/10.1111/ 1365-2435.12095

Pla L, Casanoves F, Di Rienzo J (2011) Quantifying functional biodiversity. Springer, Dordrecht

Purcel A (2009) Obce gatunki drzew i krzewów w Wielkopolskim Parku Narodowym-ich występowanie i rola w biocenozach Parku. Morena 14:35-191

Pyšek P, Křivánek M, Jarošík V (2009) Planting intensity, residence time, and species traits determine invasion success of alien woody species. Ecology 90:2734-2744. https:// doi.org/10.1890/08-0857.1

Pyšek P, Jarošík V, Pergl J et al (2014) Temperate trees and shrubs as global invaders: the relationship between invasiveness and native distribution depends on biological traits. Biol Invasions 16:577-589. https://doi.org/10.1007/ s10530-013-0600-2

Pyšek P, Manceur AM, Alba C et al (2015) Naturalization of central European plants in North America: species traits, habitats, propagule pressure, residence time. Ecology 96:762-774. https://doi.org/10.1890/14-1005.1

Rice SK, Westerman B, Federici R (2004) Impacts of the exotic, nitrogen-fixing black locust (Robinia pseudoacacia) on nitrogen-cycling in a pine-oak ecosystem. Plant Ecol 174:97-107. https://doi.org/10.1023/B:VEGE. $0000046049.21900 .5 \mathrm{a}$

Richardson DM (1998) Forestry trees as invasive aliens. Conserv Biol 12:18-26. https://doi.org/10.1111/j.1523-1739. 1998.96392.x

Richardson DM, Rejmánek M (2011) Trees and shrubs as invasive alien species-a global review. Divers Distrib 17:788-809. https://doi.org/10.1111/j.1472-4642.2011. 00782.x

Richardson DM, Pyšek P, Rejmánek M et al (2000) Naturalization and invasion of alien plants: concepts and definitions. Divers Distrib 6:93-107. https://doi.org/10.1046/j. 1472-4642.2000.00083.x

Riepšas E, Straigyté L (2008) Invasiveness and ecological effects of red oak (Quercus rubra L.) in Lithuanian forests. Balt For 14:122-130

Roberts DR, Bahn V, Ciuti S et al (2017) Cross-validation strategies for data with temporal, spatial, hierarchical, or phylogenetic structure. Ecography 40:913-929. https://doi. org/10.1111/ecog.02881

Rodríguez J, Lorenzo P, González L (2017) Different growth strategies to invade undisturbed plant communities by Acacia dealbata Link. For Ecol Manag 399:47-53. https:// doi.org/10.1016/j.foreco.2017.05.007

Sinclair JS, Arnott SE (2015) Strength in size not numbers: propagule size more important than number in sexually reproducing populations. Biol Invasions 18:497-505. https://doi.org/10.1007/s10530-015-1022-0

Starfinger U, Kowarik I, Rode M, Schepker H (2003) From desirable ornamental plant to pest to accepted addition to the flora?- the perception of an alien tree species through the centuries. Biol Invasions 5:323-335. https://doi.org/10. 1023/B:BINV.0000005573.14800.07

Stohlgren TJ, Binkley D, Chong GW et al (1999) Exotic plant species invade hot spots of native plant diversity. Ecol Monogr 69:25-46. https://doi.org/10.1890/00129615(1999)069

Stohlgren TJ, Jarnevich C, Chong GW et al (2006) Scale and plant invasions: a theory of biotic acceptance. Preslia 78:405-426

Terwei A, Zerbe S, Zeileis A et al (2013) Which are the factors controlling tree seedling establishment in North Italian floodplain forests invaded by non-native tree species? For Ecol Manag 304:192-203. https://doi.org/10.1016/j. foreco.2013.05.003

Terwei A, Zerbe S, Mölder I et al (2016) Response of floodplain understorey species to environmental gradients and tree invasion: a functional trait perspective. Biol Invasions 18:2951-2973. https://doi.org/10.1007/s10530-016-11880

Thomsen MS, Wernberg T, South PM, Schiel DR (2016) To include or not to include (the invader in community analyses)? That is the question. Biol Invasions 18:1515-1521. https://doi.org/10.1007/s10530-016-1102-9

Tilman D (1986) Resources, competition and the dynamics of plant communities. In: Crawley M (ed) Plant ecology. Blackwell Scientific Publications, Oxford, pp 51-75

Vanhellemont M, Verheyen K, Keersmaeker L et al (2009) Does Prunus serotina act as an aggressive invader in areas with a 
low propagule pressure? Biol Invasions 11:1451-1462. https://doi.org/10.1007/s10530-008-9353-8

Vítková M, Müllerová J, Sádlo J et al (2017) Black locust (Robinia pseudoacacia) beloved and despised: a story of an invasive tree in Central Europe. For Ecol Manag 384:287-302. https://doi.org/10.1016/j.foreco.2016.10. 057

Wagner V, Chytrý M, Jiménez-Alfaro B et al (2017) Alien plant invasions in European woodlands. Divers Distrib 23:969-981. https://doi.org/10.1111/ddi.12592

Westoby M (1998) A leaf-height-seed (LHS) plant ecology strategy scheme. Plant Soil 199:213-227. https://doi.org/ 10.1023/A:1004327224729

Woziwoda B, Potocki M, Sagan J et al (2014) Commercial forestry as a vector of alien tree species-the case of Quercus rubra L. introduction in Poland. Balt For 20:131-141
Yeo I-K, Johnson RA (2000) A new family of power transformations to improve normality or symmetry. Biometrika 87:954-959. https://doi.org/10.1093/biomet/87.4.954

Younginger BS, Sirová D, Cruzan MB, Ballhorn DJ (2017) Is biomass a reliable estimate of plant fitness? Appl Plant Sci 5:1600094. https://doi.org/10.3732/apps.1600094

Zerbe S, Wirth P (2006) Non-indigenous plant species and their ecological range in Central European pine (Pinus sylvestris L.) forests. Ann For Sci 63:189-203. https://doi.org/10. 1051/forest:2005111

Ziegenhagen B, Kausch W (1995) Productivity of young shaded oaks (Quercus robur L.) as corresponding to shoot morphology and leaf anatomy. For Ecol Manag 72:97-108. https://doi.org/10.1016/0378-1127(94)03482-C 